\title{
Stomatal traits in Iberian populations of Osmunda regalis(Osmundaceae, Polypodiopsida) and its relationship with bioclimatic variables
}

\author{
Mikel Lavilla', Andrea Seral'; Antonio Murciano²; Sonia Molino'; Pablo de la Fuente ${ }^{1}$ \\ \& José $M^{a}$ Gabriel y Galán' \\ ${ }^{1}$ Department of Plant Sciences I, Faculty of Biology, Universidad Complutense. Avda. Jose Antonio Nováis, 12. \\ 28040-Madrid, Spain. "Biodiversity and Taxonomy of Cryptogamic Plants" Research Group, UCM. \\ 2 Department of Applied Mathematics (Biomathematics), Faculty of Biology, Universidad Complutense. Avda. Jose \\ Antonio Nováis, 12. 28040-Madrid, Spain. "Neural Plasticity Research Group, IdISSC" and "Neuro-computing and Neuro- \\ robotics Research Group", UCM.
}

\section{Correspondence}

J. M. Gabriel y Galán

e-mail: jmgabrie@ucm.es

Received: 24 julio 2017

Accepted: 27 octubre 2017

Published on-line: diciembre 2017

\begin{abstract}
Stomata are very conserved structures in plants, which allows and control the gas exchange. This ecophysiological fact appears to be critical in the ecology and adaptation of plants to environment. Plant individuals can, among other issues, adjust size and density of the stomata to adapt themselves to hydric, thermic and light regimes. In turn, this led to the reduction of transpiration and control of water losses, which is crucial in areas with Mediterranean climate. The fern Osmunda regalis has populations in both biogeographical regions of the Iberian Peninsula (Eurosiberian and Mediterranean regions), but when locations are highly continental the populations are scarce and isolated. The objective of this study is to characterize the stomatal morphological traits in both regions, to detect possible adaptations in individuals occurring in Mediterranean locations. 26 individuals of 17 different populations were sampled. Applying microscopic techniques, 4447 observations of length and width, and 234 of density and $\mathrm{PCl}$ were done. The sampling spots were characterized by two bioclimatic indices of Emberger and Gorzynski, and also mean maximum and minimum temperature values were obtained. All the information was included in a dataset that was statistically analyzed with the software SPSS. Our results show that Osmunda regalis fronds have higher $\mathrm{PCl}$ and density values in the Eurosiberian region, as expected. Gorczynski continentality index $(\mathrm{K})$, and the mean maximum and minimum annual temperatures influences over stomatal traits. This is clearly informing that in the Mediterranean region, the temperature is an important factor that triggers stomatal adaptations of $O$. regalis to continental locations with higher levels of environmental stress. On the contrary, Emberger pluviometric index (Q) seems to be less explicative by its own. Perhaps this is related with the habitat of $O$. regalis in soils with high freatic level, fact which could lead to a more independent stomata from rainfall.
\end{abstract}

Key words: Biogeographic region, ecology, ferns, Iberian Peninsula, PCI, stomatal density

\section{Resumen}

Los estomas son unas estructuras muy conservadas en plantas y que permiten el intercambio gaseoso de las mismas con la atmósfera, un rasgo ecofisiológico clave en la adaptación y ecología de las plantas. Los individuos vegetales pueden, entre otros fenómenos, ajustar el tamaño y la densidad de sus estomas para adaptarse a las condiciones ambientales. Esto les permite, por ejemplo, evitar excesivas pérdidas por transpiración en zonas con menor disponibilidad de agua, como son las áreas bajo clima mediterráneo. El helecho Osmunda regalis, presenta poblaciones en las dos regiones biogeográficas (eurosiberiana y mediterránea) de la Península lbérica, pero bajo condiciones de excesiva continentalidad, las poblaciones son reducidas y aisladas. EI objetivo del presente estudio es caracterizar los rasgos morfológicos de esta especie en las dos regiones, para detectar posibles adaptaciones en los 
individuos que habitan zonas continentales mediterráneas. Se muestrearon 26 individuos de 17 poblaciones. Mediante técnicas microscópicas se realizaron 4447 observaciones de longitud y anchura, y 234 de densidad y PCl. Las localidades de muestreo fueron caracterizadas bioclimáticamente mediante los índices de Emberger, Gorczynski y las temperaturas medias de las máximas y de las mínimas. Todos los datos se introdujeron en un matriz que se trató estadísticamente en SPSS. Nuestros resultados muestran que las hojas de $O$. regalis presentan mayores valores de densidad estomática y $\mathrm{PCI}$ en la región eurosiberiana, lo que responde a lo esperado. El índice de continentalidad de Gorczynski $(\mathrm{K})$ y la amplitud térmica anual influyen significativamente sobre los rasgos estomáticos de la especie. Esto está informando claramente que, en la región mediterránea, la temperatura es un factor importante que dispara la adaptación de $O$. regalis a ambientes con un clima continental y, por tanto, de mayor estrés ambiental. El índice pluviométrico de Emberger $(Q)$ es menos informativo por él solo. Quizá esto esté relacionado con el hábitat de $O$. regalis, que se desarrolla normalmente en suelos de elevado nivel freático, lo que puede hacer que los estomas se manifiesten más independientes de la precipitación.

Palabras clave: Densidad estomática, ecología, helechos, $\mathrm{PCl}$, Península Ibérica, región biogeográfica

\section{Introduction}

Stomata are small pores on the surface of plant leaves and stems that control gases exchange (Hetherington \& Woodward, 2003). Stomata are strongly conserved structures since their appearance about 400 million years ago, fact considered as a key event in the evolution of vascular plants (McAdam \& Brodribb, 2012).

Morphological stomatal traits are related to hydric and photosynthetic balances, key ecophysiological parameters in plants, in relation to the environment (Meidner \& Mansfield, 1968; Xu \& Zhou, 2008). It is largely known that vascular plants can modify much of their bodies in order to adapt themselves to the environment, phenomenon in which stomata appear to be of huge importance (Franks \& Farquhar, 2007; Galmes et al., 2007). Thus, it is essential to fully understand the morphology and physiology of stomata in order to unravel how plants fit in their natural systems, and its role in the different terrestrial biomes (Reich et al., 1999; Ackerly et al., 2000; Haworth et al., 2013). The adaptation via modifying size and/or density of stomata appears to be a crucial response in this sense (Salisbury, 1927; Jones, 1998; Brownlee, 2001; Royer, 2001; Xu \& Zhou, 2008). As a very general rule, plants need to close the stomata when faced to water stress, in order to avoid an excess of transpiration that could not be balanced by water uptake from the soil (Cochard et al., 2002; Galmes et al., 2007). When water stress is prolonged (for example, under climates with an extended arid period), a simple, punctual control in stomata closure could be not enough, and variations in the morphological traits of stomata (reduction in size/ density) could then be adopted (Chaves et al., 2002; Xu \& Zhou, 2008).

The vast majority of observations about the ecological role of stomata has been done for the flowering plants (Hetherington \& Woodward, 2003; Prabhakar, 2003; Öpik \& Rolfe, 2005; Evert \& Eichhorn, 2006), while other groups of vascular plants, specifically the ferns, have received much less attention (Brodribb \& Holbrook, 2004; Gabriel y Galán et al., 2011). During the last decade, research is pointing out striking differences in the way in which fern stomata operate in comparison with those of angiosperms, specially in the pattern of signaling (Kawai et al., 2003; Doi et al., 2006). Nevertheless, to-date investigations on the relationships their environment between morphological traits of fern stomata and environment are comparatively scarce (Kato \& Imaichi, 1992; Hunt et al., 2002; Kessler et al., 2007; Kluge \& Kessler, 2007; Gabriel y Galán et al., 2011; Riano \& Briones, 2013).

The Iberian Peninsula is a notable geographical area where to develop ecological experiments related to the adaptation of fern stomata to climate, due to the existence of two different biogeographical regions. On the one hand, the Mediterranean Region (MR from now on), which extends over most of the territory, is characterized mainly by its less rainfall and the existence of a more or less prolonged arid period. On the other hand, the Eurosiberian Region (ER, from now on), which comprises the northern part of Spain and Portugal, characterized in general by its higher rainfall and 


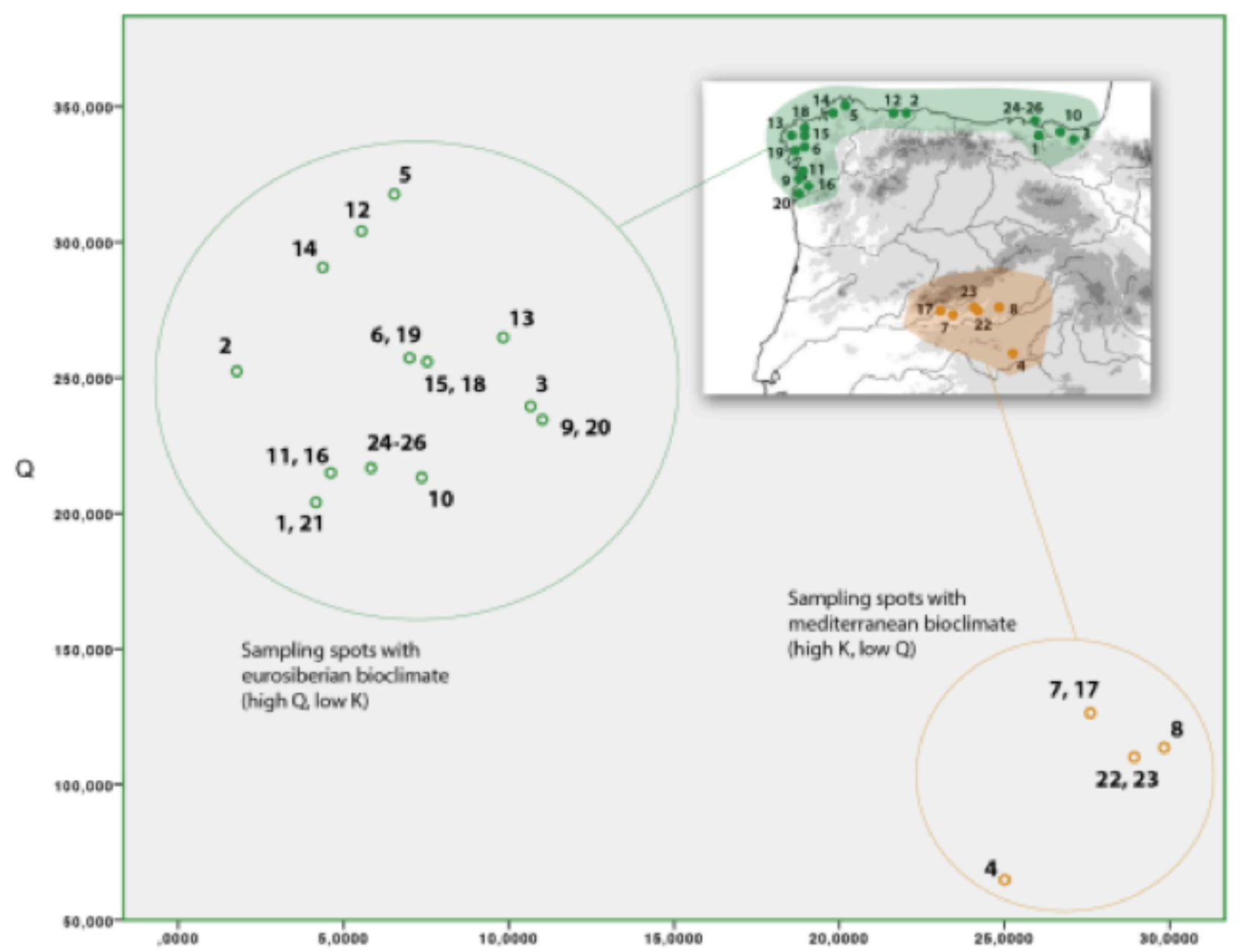

Figure 1. Sampled individuals (1-26) located in a map of the Iberian Peninsula. Spots have been plotted over a scatter graph discriminated by values of Gorczynski index $(K)$ and Embeger index $(Q)$ of the locations. Two main groups can be recognized: Mediterranean spots in orange $(K>15$ and $Q<170)$ and Eurosiberian spots in green $(K<15$ and $Q>170)$.

the absence of arid period (Rivas Martínez, 1987). In spite of their remarkable floristic differences, these two Iberian regions share some species of ferns, which either are of wide distribution, or prefer one of the regions but occur punctually in the other (Moreno et al., 2015).

The Mediterranean climate imposes strong constraints on plants and could represent an important evolutionary pressure (Joffre et al., 1999). Previous adaptations in stomatal morphological and physiological traits have been reported for plants under Mediterranean climate (Galmés et al., 2007; Galmés et al., 2013). Again, ferns have not been assessed for these issues, as far as we know, except for some works regarding general terms of species richness and distribution (Ferrer-Castan \& Vetaas, 2005; Moreno \& Lobo, 2008).

In this work we aim to study the morphological stomatal traits of ferns under two different bioclimatic regions in the Iberian Peninsula, in order to detect differences that could be due to adaptation to water stress. We have selected the species Osmunda regalis L. (Osmundaceae, Polypodiopsida) which is a common plant in the north and west part of Spain and Portugal, under oceanic climatic conditions, but have also some scattered populations in the central area of the MR (Moreno et al., 2015), under high continental conditions. Differences in morphological traits of stomata are expected between individuals from both biogeographical regions, in the sense of an adaptation of the stomatal apparatus to water stress in the Mediterranean populations. We specifically aim to: a) characterize the stomatal morphological traits of $O$. regalis in both Eurosiberian and Mediterranean regions of the Iberian Peninsula; b) compare those traits to see whether there are significant differences between bioclimatic conditions; c) try to find a bioclimatic variable, related to water stress, that could be invoked as 


\begin{tabular}{|l|c|c|c|c|}
\hline & $\begin{array}{c}\text { Length } \\
(\mu \mathrm{m})\end{array}$ & $\begin{array}{c}\text { Width } \\
(\mu \mathrm{m})\end{array}$ & Density $\left(\mathrm{st} / \mathrm{mm}^{2}\right)$ & $\mathrm{PCl}$ \\
\hline Eurosiberian & 56.38 & 45.33 & 23.28 & 7.43 \\
\hline Mediterranean & 57.22 & 46.05 & 20.51 & 6.92 \\
\hline Chi-square & 16.93 & 12.53 & 65.54 & 21.79 \\
\hline p-value & $<0.001$ & $<0.001$ & $<0.001$ & $<0.001$ \\
\hline
\end{tabular}

Table 1. Range differences and p-values for the traits considered, compared along the two biogeographical regions. The highest value for each trait has been highlighted.

key factor in the expected differences.

\section{Materials and methods}

26 individuals from 17 different populations of $O$. regalis were selected, covering both $\mathrm{ER}$ and MR (Appendix 1; Fig. 1). Samples came from both herbarium sheets (MACB) and new collections. In this latter case, vouchers of each population have been included in MACB.

Three pinnae from well-developed, undamaged fronds of each individual were collected. When possible, the three pinnae came from different fronds. In order to apply the same protocol to all the samples, the pinnae from new collections were fully dehydrated. Leaf material was hydrated for 10 minutes in distilled water and cleared for 10 minutes in $\mathrm{NaCl} 5 \%(\mathrm{v} / \mathrm{v})$. For each pinna, three hand-made peelings of the abaxial surface were made and photographed at 20x under a compound light microscope (Nikon Labophot-2 with a camera Coolpix MDC). Photographs were processed with the software Piximètre (Henriot \& Cheype, 2012). For each optical field, we measured length $(L$, in $\mu \mathrm{m}$ ) and width (W, in $\mu \mathrm{m}$ ) of all stomata (we did not consider stomata with less than the $2 / 3$ of its length in the field), and we obtained one measure of stomatal density ( $D$, as number of stomata per $\mathrm{mm}^{2}$ ). Also, to get a more functional view of the stomatal traits, the adimensional variable $\mathrm{PCl}$ (Potential Conductance Index (PCI)) was calculated for each optical field as follows: $\mathrm{PCl}=\mathrm{L}^{2}$ $\cdot D \cdot 10^{-4}$. This variable is a proxy for the potentially transpirant area of a frond, through the estimation of the surface of all the stomatal pores (Holland \& Richardson, 2009).

The total of measurements reached 4447 for $\mathrm{L}$ and $\mathrm{W}$, and 234 for $\mathrm{D}$ and $\mathrm{PCl}$.

Climatic parameters for each population were obtained from the database SIGA (SIGA, 2016). Unfortunately, we were unable to calculate a precise index of aridity due to the lack of evapotranspiration data for many of the climatic stations. Thus, we rely our analyses to the use of rainfall and annual thermic interval values. The variables we included were: annual rainfall $\left(P\right.$, in $\mathrm{mm}$ or $\left.1 / \mathrm{m}^{2}\right)$, mean temperature of the warmest month $\left(\operatorname{Tmax}\right.$, in $\left.{ }^{\circ} \mathrm{C}\right)$, mean temperature of the coldest month (Tmin, in ${ }^{\circ} \mathrm{C}$ ), annual mean maximum temperature (Tmmax, in ${ }^{\circ} \mathrm{C}$ ), and annual mean minimum temperature (Tmmin $\mathrm{m}$, in ${ }^{\circ} \mathrm{C}$ ) temperatures. In order to properly discriminate our locations, we calculate the following bioclimatic indices (Rivas-Martinez \& Rivas-Saenz, 1996-2017) (Fig. 1):

Emberger Pluviometric Index (Q):

$$
Q=100 \cdot \frac{P}{T_{\max }^{2}-T_{\min }^{2}} Q=100 \cdot \frac{P}{T_{\max }^{2}-T_{\min }^{2}}
$$

Gorczynski Continentality Index (K):

$$
K=1.7 \cdot \frac{\left(T_{\max }-T_{\min }\right)}{\operatorname{sen}(L)}-20.4
$$

(where $\mathrm{L}=$ location latitude).

Statistical analyses were made with SPSS ${ }^{\circ}$ software using non-parametric test due to the absence of normality in the data. Main test for this
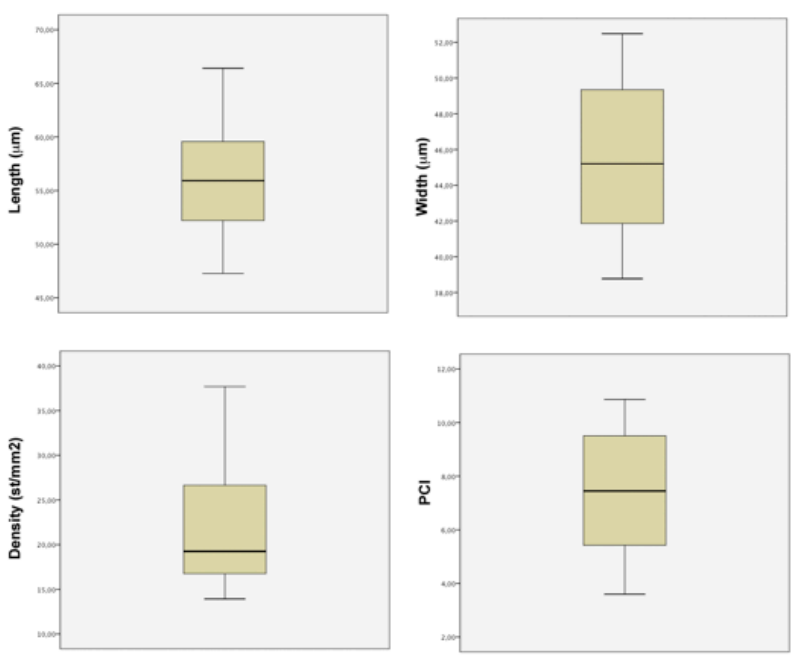

Figure 2. Box and whisker plots for the morphological stomatal traits of $O$. regalis. 
study were Spearman test for correlations between traits, Kruskal-Wallis for rank comparison between regions, and linear models for correlations between traits and climatic variables. The signification level was $\alpha=0.05$.

\section{Results}

\section{Biometrical characterization}

Stomata in $O$. regalis have a mean size of $56.56 \pm 5.05 \times 45.49 \pm 4.08 \mu \mathrm{m}$. Stomatal mean density is $22.68 \pm 6.80$ stomata $/ \mathrm{mm}^{2}$ and the mean $\mathrm{PCl}$ is $7.33 \pm 2.24$ (Fig. 2).

Besides the basic biometrical characterization, we were interested in the existence of correlations between the stomatal traits. Thus, we made a Spearman correlation analysis combining all the considered traits, except $\mathrm{PCl}$, due to its calculated nature from the others. Our results show a positive and moderately high correlation between length and width ( $L^{*} W: \rho=0.647, p<0.01$; Fig. 3 ), and inverse and moderately low correlations between those variables and density $\left(L^{*} D: \rho=-0.056\right.$, $\left.p<0.01 ; W^{*} D: \rho=-0.065 ; p<0.01\right)$.

\section{Differences in stomatal traits between bioclimatic regions \\ We detected statistically significant differences between bioclimatic regions for all the stomatal traits studied, through a Kruskal-Wallis test (Table 1, Fig. 4). Eurosiberan individuals have higher density and $\mathrm{PCl}$, whilst Mediterranean individuals have higher length and width.}

Stomatal traits correlations with bioclimatic variables

In order to detect potential relationships between stomatal traits and bioclimatic variables, we made use of the mentioned Emberger and Gorczynski indices, as they are a combination of climatic variables (rainfall and thermic amplitude), and of the factors Tmmax and Tmmin, all of them

\begin{tabular}{|l|c|c|c|c|}
\hline & $\mathrm{Q}$ & $\mathrm{K}$ & Tmmax & Tmmin \\
\hline Length & $0.130^{* *}$ & -0.009 & $-0.120^{* *}$ & $-0.160^{* *}$ \\
\hline Width & $0.104^{* *}$ & -0.025 & $-0.111^{* *}$ & $-0.111^{* *}$ \\
\hline Density & 0.029 & $-0.092^{* *}$ & $-0.084^{* *}$ & $0.086^{* *}$ \\
\hline PCl & $0.069^{* *}$ & $-0.073^{* *}$ & $-0.127^{* *}$ & -0.016 \\
\hline
\end{tabular}

Table 2. Bivariate correlations values $(\rho)$ between stomatal traits and bioclimatic indices $(\mathrm{Q}=$ Emberger, $\mathrm{K}=$ Gorczynski; Tmmax= annual mean maxium temperature; and Tmmin= annual mean minimum temperature). indicates highly significant correlation ( $p$-value<0.001).

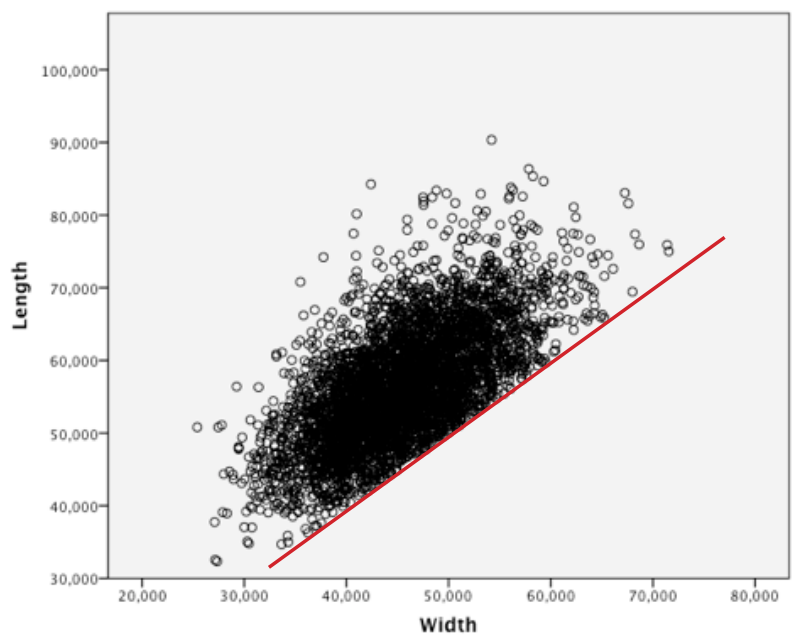

Figure 3. Scatter plot showing a high correlation between stomatal length and width in $O$. regalis. A linear regression equation has been calculated $(y=15.35+0.53 x)$, which shows a $R^{2}=0.431$. The red line defines a width threshold that is limiting the minimum effective size of stomata in this species.

with proved ecological significance for the plants. Thus, we carried out Spearman correlations analyses for the stomatal traits and all of these bioclimatic variables (Table 2):

As it can be shown, $Q$ is directly correlated with stomatal size ( $\mathrm{L}$ and $\mathrm{W}$ ) and with $\mathrm{PCl}$, but is seems to be independent from $\mathrm{D}$. $\mathrm{K}$ is independent from stomatal size but affects negatively to $\mathrm{D}$ and $\mathrm{PCl}$. Tmmax is inversely correlated with all the stomatal traits, whilst Tmmin correlates inversely with size, directly with $D$ and appears to be independent from $\mathrm{PCl}$.

The non-significant correlations observed for stomatal traits that are expected to change with the selected climatic variables, move us to think whether there could be a differential response within biogeographical regions. Thus, we conducted the same Spearman correlation analysis with the data segregated by region (Table 3 ).

Some striking results appeared compared to the general correlations of Table 2. First, the four non-significant correlations that resulted calculated, now appeared to be significant within each region: $Q$ is negatively affecting to $D$ in both regions, $K$ is negatively affecting to $L$ and $W$ in both regions, and Tmmin affects to $\mathrm{PCl}$ in both regions, positively in the ER region and negatively in the MR. Second, a differential response of the correlation between regions has been detected in many of the cases. Briefly, these new results are as follows: $Q$ is positively correlated to $\mathrm{L}$ and $\mathrm{PCl}$ in the $\mathrm{ER}$ but negatively in the MR; $K$ is positively correlated to $D$ 


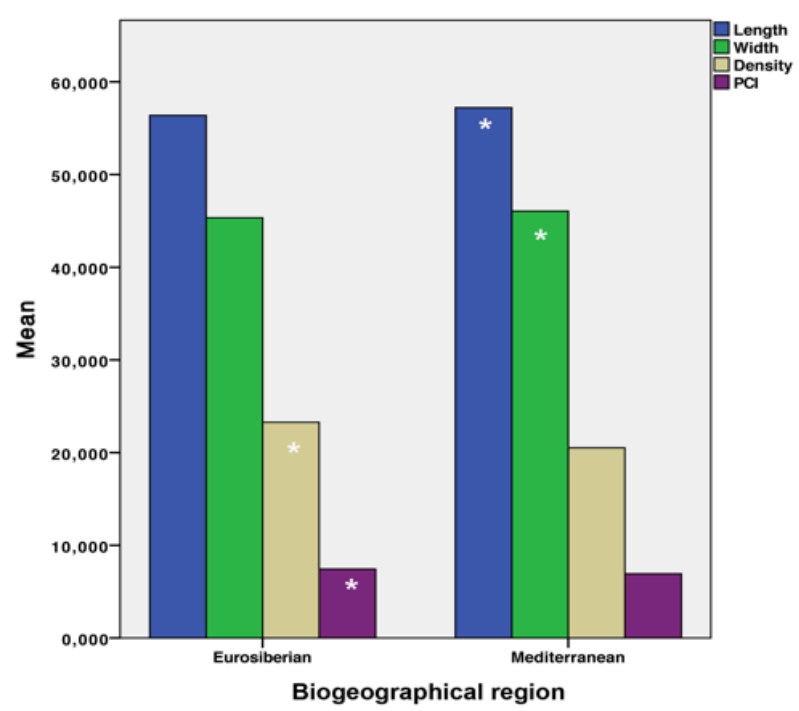

Figure 4. Bar graphs showing values of the four considered traits for each of the biogeographical region. * indicates statistical significant differences between regions for each trait, and has been drawn over the highest value.

and $\mathrm{PCl}$ in the ER but negatively in the MR; Tmmax is positively correlated to $\mathrm{D}$ and $\mathrm{PCl}$ in the ER but negatively in the MR; finally, Tmmin is negatively correlated to $\mathrm{W}$ and $\mathrm{D}$ in the MR but positively to $\mathrm{D}$ in the ER, while is independent from W.

\section{Discussion}

Gorczynski's (K) and Embeger's (Q) indices are useful to discriminate the two biogeographical regions, Eurosiberian and Mediterranean, present in the Iberian Peninsula. The discrimination is due to the bioclimatic parameters included in the indices and show the less frequency of rainfall (low $Q$ ) and high continentality (high K) in the MR, whereas these values are the opposite in the ER, as many authors have pointed before (Rivas Martínez,
1987). Thus, based on these indices, we were able to strongly differentiate between our samples in two main groups. Also, based on these indices, we could assembly several climatic parameters to which stomata of $O$. regalis are presumably responding to.

The stomata of $O$. regalis observed in this study are quite longer than those measured in previous works (Wagner-Cremer et al., 2007), from plants collected in tropical environments of Florida (USA). The differences in climatic parameters between the American localities of that study and ours could perhaps explain the differences in the stomatal lengths. We detected a strong correlation between length and width of stomata in $O$. regalis, which could be due to a genetic control of stomatal size. An endogenous control has been yet proved for these stomatal traits for plants in general (Metcalfe \& Chalk, 1979), and also it has been related to diagnostic purposes in some fern species (Gabriel y Galán et al., 2011). Furthermore, our results show an apparent minimum threshold in stomatal width that is limiting the effective size of stomata in $O$. regalis. This could be a response of an allometric phenomenon, that has been detected in previous works for the stomata of vascular plants in general (Boer et al., 2016).

Stomata functional traits in $O$. regalis seem to adapt to the Mediterranean climate, as expected, as these populations have lower density and less $\mathrm{PCl}$ than the ER individuals, even though the stomatal size is bigger here. This may indicate that water stress control is achieved through density rather than size modification, and follows the previously exposed idea of the endogenous, genetic control of the size of stomata (Metcalfe \& Chalk, 1979). Changes in stomatal adaptation to environment could be achieved by ferns via a balance between size/density of stomata and size of epidermal cells (Gabriel y Galán et al., 2011). However, in the case of $O$. regalis, we detected that Mediterranean

\begin{tabular}{|c|c|c|c|c|c|c|c|c|}
\hline & \multicolumn{2}{|c|}{ Q } & \multicolumn{2}{c|}{ K } & \multicolumn{2}{c|}{ Tmmax } & \multicolumn{2}{c|}{ Tmmin } \\
\hline & ER & MR & ER & MR & ER & MR & ER & MR \\
\hline Length & $0.466^{* *}$ & -0.062 & $-0.192^{* *}$ & $-0.173^{* *}$ & $-0.303^{* *}$ & $-0.415^{* *}$ & $-0.084^{* *}$ & $-0.552^{* *}$ \\
\hline Width & $0.361^{* *}$ & $0.132^{* *}$ & $-0.286^{* *}$ & $-0.092^{* *}$ & $-0.311^{* *}$ & $-0.351^{* *}$ & -0.010 & $-0.521^{* *}$ \\
\hline Density & $-0.138^{* *}$ & $-0.771^{* *}$ & $0.301^{* *}$ & $-0.778^{* *}$ & $0.383^{* *}$ & $-0.738^{* *}$ & $0.089^{* *}$ & $-0.585^{* *}$ \\
\hline PCl & $0.142^{* *}$ & $-0.588^{* *}$ & $0.085^{* *}$ & $-0.641^{* *}$ & $0.127^{* *}$ & $-0.734^{* *}$ & $0.060^{* *}$ & $-0.692^{* *}$ \\
\hline
\end{tabular}

Table 3. Bivariate correlations values $(\rho)$ between stomatal traits and bioclimatic indices $(Q=E m b e r g e r, K=G o r c z y n s k i$; Tmmax = annual mean maxium temperature; and Tmmin= annual mean minimum temperature), for each of the biogeographical regions (ER=Eurosiberian Region; MR=Mediterranean Region). " indicates highly significant correlation (p-value<0.001). 
plants increase the stomatal size and decrease the density (compared to those living under ER), therefore it is possible that the adaptations could be done without changes in the epidermal cells.

$Q$ shows an expected relationship with stomatal traits of $O$. regalis: an increase in $Q$ implies increasing rainfall or reducing thermic interval (i.e. smoother temperatures), and both allows $O$. regalis plants to grow increasing the transpiration $(\mathrm{PCl})$ because there is enough water to balance the stomatal losses (Galmes et al., 2007). But the reduction in the $\mathrm{PCl}$ of the Mediterranean locations with an increasing $Q$ is not easily explained with our data. Perhaps, as $O$. regalis is a species that lives in riverbanks, the stomata are quite independent on rainfall because there is enough water available from the freatic level (Cowan, 1977; Galmes et al., 2007). But in the MR, the annual variation in the rivers' flow perhaps derives in a more sensitiveness of this populations to an additional amount of rainfall.

$\mathrm{K}$ also influences the stomata of $O$. regalis as expected: an increasing in $\mathrm{K}$ implies a harder thermic interval, with more extreme temperatures of the hottest and coldest months; under this scenario, $O$. regalis tends to reduce the transpiration, by adapting the density of stomata (less stomata per unit of area), which indeed derived in a reduction of potential hydraulic conductance, with independence of the stomatal size. This parameter $\mathrm{K}$ is also affecting differentially in each region: while an increase of $\mathrm{K}$ comes to an overall reduction of the stomatal size in both regions, it promotes an increase on $\mathrm{D}$ and $\mathrm{PCl}$ in the $\mathrm{ER}$ but produces a high reduction of $\mathrm{D}$ and $\mathrm{PCl}$ in $\mathrm{MA}$. Tmmax and Tmmin have the same effect: increasing values of both factors induce a reduction of stomatal size in ER and MR; but while in ER these factors produce an increase in $\mathrm{D}$ and $\mathrm{PCl}, \mathrm{MR}$ populations show a highly-correlated reduction of $\mathrm{D}$ and $\mathrm{PCl}$. All this responses of $O$. regalis are pointing towards an expected adaptation of the Mediterranean individuals, as so have to do the Mediterranean plants in general (Joffre et al., 1999; Galmés et al., 2007; Galmés etal., 2013). Regarding temperatures, an increase in Tmmax is clearly affecting in the same way, probably by means of increasing the potential evapotranspiration (Schulze et al., 1973), which would lead to $O$. regalis individuals facing to less water availability, so reduction on size and density is needed. Other case is the influence of increasing Tmmin, which apparently has the same effect of reducing size, but a direct correlation with the density renders an independent $\mathrm{PCI}$ from mean lows temperatures; i.e., apparently, the potential transpiration is balanced.

\section{Conclusions}

We have characterized the stomata of $O$. regalis in the Iberian Peninsula, considering its appearance in the Eurosiberian area and part of the oceanic Mediterranean area, but having also some other isolated populations in continental, Mediterranean locations.

Osmunda regalis fronds show higher $\mathrm{PCl}$ and density values in the Eurosiberian region, as rainfall exerts a positive effect on transpiration, due to a higher water availability that balance losses through transpiration.

Gorczynski continentality index (K), and the mean maximum and minium annual temperatures influences over stomatal traits. This is clearly informing that in the Mediterranean region (with higher $\mathrm{K}$ and greater thermic interval), the temperature is an important factor to detect adaptations of stomata to water stress in $O$. regalis. On the contrary, Emberger pluviometric index $(Q)$ seems to be less explicative by its own. Perhaps the habitat of $O$. regalis makes the considerations of the rainfall somewhat odd in searching for different stomatal responses of the MR populations of this species.

\section{Acknowledgements}

This work has been partially funded through Research Groups funding program, UCM 810810 "Biodiversidad y Taxonomía de Plantas Criptógamas". The authors would like to thank the director of MACB herbarium for her willingness to provide part of the material needed.

\section{Appendix 1}

List of the biological material studied, ordered by provinces and sampling spots, with basic voucher information. The number of the 26 individuals is indicated in parenthesis and correspond to that of figure 1.

Asturias: Cerca de Brieves, Valdés, M. C. Fernández Carvajal et al., 3/6/93, MACB 59189 (ind. 12). Cudillero, Ballota (Sta Marina), A. Izuzquiza, 18/8/96, MACB 72287 (ind. 2). Ávila: Valle del Tiétar (CasaviejaMijares), D. Sánchez-Mata \& V. de la Fuente, 13/5/85, MACB 18736 (ind. 8). Cáceres: Valdastillas, E. Rico, 28/5/75, MACB 11409 (inds. 7 y 17). Villanueva de la Vera, J. M. Gabriel y Galán \& Puelles, 15/11/14, MACB 109360 (inds. 22 y 23). Cantabria: Liendo, J. M. Gabriel y Galán \& Puelles, 6/12/14, MACB 107332 (inds. 2426). Ramales de la Victoria, Pondra, E. Rodríguez \& $M$. Herrera, 19/9/87, MACB 31127 (inds. 1 y 21). Ciudad Real: Cabañeros, Arroyo del Chorrerón, I. Vaquero, H. Sainz \& H. Costa, 29/6/90, MACB 41084 (ind. 4). Coruña: A Baña, río Tambre, L. G. Quintanilla \& B. Pias, 
15/11/97, MACB 92442 (inds. 15 y 18). As Pontes de García Rodríguez, Gil, Gil, T., 28/6/99, MACB 75118 (ind. 5). Cara Monte Pindo hacia Fleiro, R. Iglesias Louzán, 14/5/95, MACB 63009 (ind. 13). Monfero, Marola Grande, Arroyo Isalonga, F. J. Silva-Pando \& A. Prunell Tuduri, 6/11/93, MACB 59135 (ind. 14). Ribeira, Parque Natural, L. G. Quintanilla, 15/6/97, MACB 92410 (inds. 6 y 19). Pontevedra: Cangas de Morrazo, Monte Castelo, P. Samartín Bienzobas \& L.A. Samartín Bienzobas, 21/10/86, MACB 31079 (ind. 11 y 16). Porriño, Gandaras de Budiño, F. J. Silva-Pando \& E. Valdés-Bermejo, 16/6/87, MACB 30874 (inds. 9 y 20). Vizcaya: Leioa, J. Oidi, C. Roscher \& M. Herrera, 1/10/91, MACB 43421 (ind.. 10). Durango, Euba, E. Sarrionaindia, 26/10/95, MACB 62931 (ind. 3).

\section{References}

Ackerly, D. D., et al. (2000). The evolution of plant ecophysiological traits: Recent advances and future directions. Bioscience 50: 979-995.

Boer, H. J., et al. (2016). Optimal allocation of leaf epidermal area for gas exchange. New Phytologist 210: 1219-1228.

Brodribb, T. J. \& Holbrook, N. M. (2004). Stomatal protection against hydraulic failure: a comparison of coexisting ferns and angiosperms. New Phytologist 162: 663-670.

Brownlee, C. (2001). The long and the short of stomatal density signals. Trends in Plant Science 6: 441-442.

Chaves, M. M., et al. (2002). How plants cope with water stress in the field. Photosynthesis and growth. Annals of Botany 89: 907-916.

Cochard, H., et al. (2002). Unraveling the effects of plant hydraulics on stomatal closure during water stress in walnut. Plant Physiology 128: 282-290.

Cowan, I. R. (1977). Stomatal behaviour and environment. Advance in Botanical Research 4: 117-228.

Doi, M., et al. (2006). The fern Adiantum capillus-veneris lacks stomatal responses to blue light. Plant and Cell Physiology 47: 748-755.

Evert, R. F. \& Eichhorn, S. E. (2006). Esau's Plant Anatomy. New York, USA. Wiley.

Ferrer-Castan, D. \& Vetaas, O. R. (2005). Pteridophyte richness, climate and topography in the Iberian Peninsula: comparing spatial and nonspatial models of richness patterns. Global Ecology and Biogeography 14: 155-165.

Franks, P. J. \& Farquhar, G. D. (2007). The mechanical diversity of stomata and its significance in gasexchange control. Plant Physiology 143: 78-87.

Gabriel y Galán, J. M., et al. (2011). Biometry of stomata in Blechnum species (Blechnaceae) with some taxonomic and ecological implications for the ferns. Revista De Biologia Tropical 59: 403-415.

Galmés, J., et al. (2007). Water relations and stomatal characteristics of Mediterranean plants with different growth forms and leaf habits: responses to water stress and recovery. Plant and Soil 290: 139-155.

Galmés, J., et al. (2007). Photosynthetic limitations in response to water stress and recovery in Mediterranean plants with different growth forms. New
Phytologist 175: 81-93.

Galmés, J., et al. (2013). Leaf responses to drought stress in Mediterranean accessions of Solanum lycopersicum: anatomical adaptations in relation to gas exchange parameters. Plant, Cell \& Environment 36: 920-935.

Haworth, M., et al. (2013). Co-ordination of physiological and morphological responses of stomata to elevated [CO2] in vascular plants. Oecologia 171: 71-82.

Henriot, A. \& Cheype, J. L. (2012). Piximètre, la measure des dimensions sur images. In.

Hetherington, A. M. \& Woodward, F. I. (2003). The role of stomata in sensing and driving environmental change. Nature 424: 901-908.

Holland, N. \& Richardson, A. D. (2009). Stomatal length correlates with elevation of growth in four temperate species. Journal of Sustainable Forestry 28: 63-73.

Hunt, M. A., et al. (2002). Ecophysiology of the soft tree fern, Dicksonia antarctica labill. Austral Ecology 27: 360-368.

Joffre, R., et al. (1999). Functional attributes in Mediterranean-type ecosystems. In: F. I. Pugnaire \& F. Valladares (eds.), Handbook of Functional Plant Ecology: 347-380. New York.

Jones, H. G. (1998). Stomatal control of photosynthesis and transpiration. Journal of Experimental Botany 49: 387-398.

Kato, M. \& Imaichi, R. (1992). Leaf anatomy of tropical fern rheophytes, with its evolutionary and ecological implications. Canadian Journal of Botany 70: 165-174.

Kawai, H., et al. (2003). Responses of ferns to red light are mediated by an unconventional photoreceptor. Nature 421: 287-290.

Kessler, M., et al. (2007). Patterns of morphological leaf traits among pteridophytes along humidity and temperature gradients in the Bolivian Andes. Functional Plant Biology 34: 963-971.

Kluge, J. \& Kessler, M. (2007). Morphological charactersitics of fern assemblages along an elevational gradient, patterns and causes. Ecotropica 13: 27-43.

Mcadam, S. a. M. \& Brodribb, T. J. (2012). Stomatal innovation and the rise of seed plants. Ecology Letters 15: 1-8.

Meidner, H. \& Mansfield, T. (1968). Physiology of stomata. London, UK. McGraw-Hill.

Metcalfe, C. R. \& Chalk, L. (1979). Anatomy of the Dicotyledons. London, UK. Clarendon.

Moreno, J. C. \& Lobo, J. M. (2008). Iberian-Balearic fern regions and their explanatory variables. Plant Ecology 198: 149-167.

Moreno, J. C., et al. (2015). Atlas de los pteridófitos de la Península Ibérica e Islas Baleares. Acta Botanica Malacitana 40: 5-55.

Öpik, H. \& Rolfe, S. A. (2005). The physiology of flowering plants. Cambridge, UK. Cambridge University Press.

Prabhakar, M. (2003). Structure, delimitation, nomenclature and classification of stomata. Acta Botanica Sinica 462: 242-252.

Reich, P. B., et al. (1999). Generality of leaf trait relationships: A test across six biomes. Ecology 80: 1955-1969. 
Riano, K. \& Briones, O. (2013). Leaf physiological response to light environment of three tree fern species in a Mexican cloud forest. Journal of Tropical Ecology 29: 217-228.

Rivas Martínez, S. (1987). Nociones sobre fitosolociología, biogeografía y bioclimatología. In: M. Peinado \& S. Rivas Martínez (eds.), La vegetación de España: 19-45. Alcalá de Henares.

Rivas-Martinez, S. \& Rivas-Saenz, S. (1996-2017). Worldwide Bioclimatic Classification System. http:// www.globalbioclimatics.org/. Phytosociological Research Center, Spain (accessed october 2016). In.

Royer, D. L. (2001). Stomatal density and stomatal index as indicators of paleoatmospheric $\mathrm{CO} 2$ concentration. Review of Palaeobotany and Palynology 114: 1-28.

Salisbury, E. J. (1927). On the causes and ecological significance of stomatal frequency, with special reference to the woodland flora. Philosophical Transactions of the Royal Society B 216: 1-65.

Schulze, E. D., et al. (1973). Stomatal responses to changes in temperature at increasing water stress. Planta 110: 29-42.

SIGA (2016). Sistema de Información Geográfica de Datos Agrarios (http://sig.mapama.es/siga/). Ministerio de Agricultura, Pesca, Alimentación y Medio Ambiente. España (accessed oct 2016). In.

Wagner-Cremer, F., et al. (2007). Influence of ontogeny and atmospheric $\mathrm{CO} 2$ on stomata parameters of Osmunda regalis. CFS Courier Forschungsinstitut Senckenberg 258: 183-189.

Xu, Z. \& Zhou, G. (2008). Responses of leaf stomatal density to water status and its relationship with photosynthesis in a grass. Journal of Experimental Botany 59: 3317-3325. 
